\title{
システム開発プロジェクトにおける 手戻りリスクを考慮したタスク優先ルール設計に関する研究
}

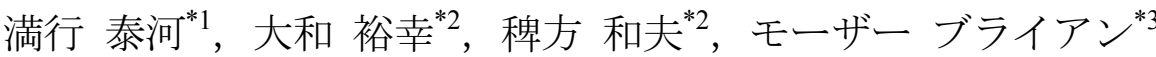 \\ 磯沼 大 $^{* 4}$, 岡田 伊策 ${ }^{*}$, 笈田 佳彰 ${ }^{* 5}$
}

\section{A study on designing task priority rule considering rework risk of system development project}

\author{
Taiga MITSUYUKI ${ }^{* 1}$, Hiroyuki YAMATO*2 ${ }^{* 2}$ Kazuo HIEKATA ${ }^{* 2}$, Bryan MOSER $^{* 3}$, \\ Masaru ISONUMA ${ }^{* 4}$, Isaac OKADA ${ }^{* 5}$ and Yoshiaki OIDA*5 \\ ${ }^{*_{1},{ }^{* 4}}$ Graduate School of Engineering, the University of Tokyo \\ 7-3-1 Hongo, Bunkyo-ku, Tokyo 113-8656, Japan \\ ${ }_{2, * 3}$ Graduate School of Frontier Sciences, the University of Tokyo \\ 5-1-5 Kashiwanoha, Kashiwa, Chiba 277-8563, Japan \\ ${ }^{* 5}$ Systems Integration Technology Unit, FUJITSU LIMITED \\ 1-17-25 Shin-Kamata, Ota-ku, Tokyo 144-8588, Japan
}

\section{Received 29 August 2015}

\begin{abstract}
This paper proposes a methodology for designing task priority rule considering rework risk of system development project. In this paper, a process simulation considering reworks and the methodology for calculating optimal task priority rule by using genetic algorithm are developed. The process simulation considering reworks can be done by using the information of target system, rework probabilities, worker's skill and task priority rule. Proposed task priority rule consists of several dispatching rules that are related to each task. In developed process simulation, task priority rule can define which task is done preferentially in each time. In this paper, five dispatching rules are introduced for creating proposed task priority rule. By using developed process simulation, Monte-Carlo method and genetic algorithm, optimal task priority rule can be calculated from the viewpoint of average time required of target system development project. In this paper, proposed methodology was applied to a system development project. Results show that proposed task priority rule can get the lower average time required than other dispatching rule considering the structure of workflow and rework information.
\end{abstract}

Key words : Task priority rule, Discrete event simulation, Rework, Monte-Calro simulation, Dispatching rule, Genetic algorithm

\section{1. 緒言}

銀行の ATM システムや企業の人事情報システムなどに代表される情報システム構築を目的としたシステム開 発プロジェクトでは標準化された開発プロセスが存在し，特に大規模なシステム開発プロジェクトでは，ウォー ターフォール型開発プロセスが採用されることが多い. ウォーターフォール型の開発プロセスとは, 設計, 開発, テストなどの各タスクについて, 前タスクが完了次第, 次のタスクに進むという一直線のプロセスである. また, 開発対象となるシステムは複数のモジュールによって構成され，モジュール単位で設計，開発，単体テストが行 われた後, 複数のモジュールの結合テストを行うことによって開発が進められる.

No.15-00474 [DOI:10.1299/transjsme.15-00474], J-STAGE Advance Publication date : 4 March, 2016

${ }^{* 1}$ 正員, 東京大学大学院工学系研究科 (下113-8656 東京都文京区本郷 7-3-1)

*2 正員, 東京大学大学院新領域創成科学研究科（†277-8563 千葉県柏市柏の葉 5-1-5)

*3 東京大学大学院新領域創成科学研究科

${ }^{* 4}$ 東京大学大学院工学系研究科

*5 富士通（株）システム技術統括部（†144-8588 東京都大田区新蒲田 1-17-25）

E-mail of corresponding author: mitsuyuki@sys.t.u-tokyo.ac.jp 
Mitsuyuki, Yamato, Hiekata, Moser, Isonuma, Okada and Oida, Transactions of the JSME (in Japanese), Vol.82, No.835 (2016)

システム開発プロジェクトにおける特徵として，設計や開発タスクのミスが後に発見され，そのタスクをやり 直すという手戻りが頻繁に発生する点が挙げられる， ウォーターフォール型の開発プロセスでは，前タスクにお ける成果物に誤りは無いという前提で進むプロセスであるが，実際には顧客要求の変更などや設計のミスなどの 予測できない事象によって手戻りが発生し，その結果としてタスクを繰り返し行う必要がある. 例えば, 詳細設 計の詋りが結合テストで発見された場合，詳細設計まで手戻りが発生し，更にそれに依存するプログラムの設計 や開発もやり直すことになり, 結果としてプロジェクトに大きな損害を与えることになる. 手戻りの発生を減少 するための対策として, システム開発における要件定義の精緻化や, 短期間にプロトタイプシステムを繰り返し 作成するアジャイル型の開発プロセスを採用するなどの対策が考えられる．しかしながら，システム開発の現場 では，上記の対応策を採用したとしても本質的に手戻りが発生する確率をゼロにすることは難しい，一方で，

Moser らは，プロジェクトの計画段階で手戻りの要因となるリスクの発生確率とその影響を予め把握することが 重要であると述べている（Moser et al., 2015)．手戻りの影響を把握するには，離散イベントシミュレーションな どのシミュレーション技術を用いることが考えられるが，対象とするプロジェクトのワークフローが複雑になる と，どのタスクを優先して行うかによってプロジェクトにおける手戻りの影響の評価が変わってしまうという問 題がある. このため, 手戻りのリスクを考慮しつつ, タスク優先ルール, 寸なわち時刻ごとに実施可能なタスク のうちどのタスクを優先して実施するかのルールを適切に設計することは, システム開発プロジェクトにおける 手戻りの影響を正確に見積もることにつながり，同時に手戻りの影響を考慮したスケジュール設計を支援するこ とにもつながる.

本研究で扱うシステム開発プロジェクトにおけるスケジュール設計は, 資源制約付きプロジェクトスケジュー リング問題（Resource-Constrained Project Scheduling Problem； RCPSP）（Hartmann, 1998）という問題に分類され る. RCPSP は, 各タスクについて工数と必要なリソースの種類と量, 制約となる各リソースの総量を定義し, リ ソースの量を制約条件としながら期間が最小となるようにスケジュールを設定する問題である．この問題は NP 困難であることが知られており，ディスパッチングルール（岩村他，2014）（阪口他，2015）の考え方を導入した タスク優先ルールとヒューリスティック探索を用いて近似解を得る手法が多数提案されている（Kolisch, 1996）

（Merkle et al., 2002）（Valls et al., 2008）テディスパッチングルールとは，ある1つのタスクが終了した時点ごとに 作業待ちになっているタスク群から次に実施するタスクを選択寸るルールのことであり, 様々な種類のディスパ ッチングルールが提案されている. また, システム開発を含めたプロジェクトをRCPSP の形でモデル化し, 離散 イベントシミュレーションによって計算し評価する研究も多数行われている. 例えば, Suzuki らは Process Management Tool というシミュレーションツールを開発し, 製造業を対象にその効果を実証している (Suzuki et al., 2012; 鈴木他, 2014). Mitsuyuki らは複数のディスパッチングルールを組み合わせて, 設備の数や単位時間当たり における電力使用量の制限を満たすように造船所のブロック製造スケジューリングを行う手法を提案している

(Mitsuyuki et al., 2014). 上記のように, 実際のプロジェクトをRCPSP の形にモデル化し, 離散イベントシミュ レーションを用いて解く研究は多数存在するが，いずれも手戻りのことは考えられていない.

手戻りを考慮したプロジェクトスケジューリング手法として, プロジェクトのシミュレーションの中で手戻り の発生を確率的に扱う手法が提案されている. Cho らは, タスクを平行に進めた場合における情報の受け渡しの 失敗による 3 種類の手戻りを考慮し, RCPSP の近似解法であるシリアルスケジューリング法の中で, 手戻りを考 慮した優先ルールを用いてプロジェクトスケジュールを設計, 評価する手法を提案している (Cho and Eppinger, 2005). 同様に, Lu らは手戻りに対応寸るために, 各タスクの必要作業期間を, 手戻りの発生を考慮した場合に 追加で発生する作業期間を加えた形で各タスクの優先度を判断するタスク優先ルールを提案している（Lu and Li, 2008).これらの研究では, プロジェクトシミュレーションにおけるタスク順序決定について単一のタスク優先ル ールを用いているが, 複数のルールを組み合わせたタスク優先ルールを導入することで, 手戻りに対してより柔 軟で目的に合ったスケジュールが設計可能になると考えられる.

本研究では, システム開発プロジェクトにおける手戻りを含んだスケジュール設計のためのタスク優先ルール 設計手法を提案する. 具体的には, 手戻りを考慮したプロセスシミュレーションと遺伝的アルゴリズムを用いて, 複数のディスパッチングルールによって構成されるタスク優先ルールを決定する手法を提案する. また，システ ム開発プロジェクトのケーススタディにおいて, 提案手法で決定したタスク優先ルールの妥当性を検証する. 


\section{2. 提案手法}

提案手法の概要を図 1 に示寸，提案手法は大きく分けて，(1)開発対象となるシステム構成の情報とシステム開 発プロジェクトを実施する際の人員や手戻り確率を入力としたプロセスシミュレーションと, (2)手戻りを考慮し

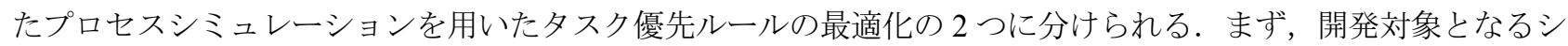
ステム構成からタスクの依存関係を導出し，導出したタスク群に対して工数の情報とタスク間の手戻り確率情報 を入力する. 次に, 各タスクを担当する人員のスキルセット情報を作成する. これらの情報を入力として, 各夕 スクに対応する形で登録されたディスパッチングルール群によって構成されるタスク優先ルールを用いて手戻り を考慮したプロセスシミュレーションにより，対象とするシステム開発プロジェクトがどのように実施されるか を把握する. また，プロセスシミュレーションの結果における所要時間の平均值を目的関数として，遺伝的アル ゴリズムを用いて適切なタスク優先ルールの探索を行う.

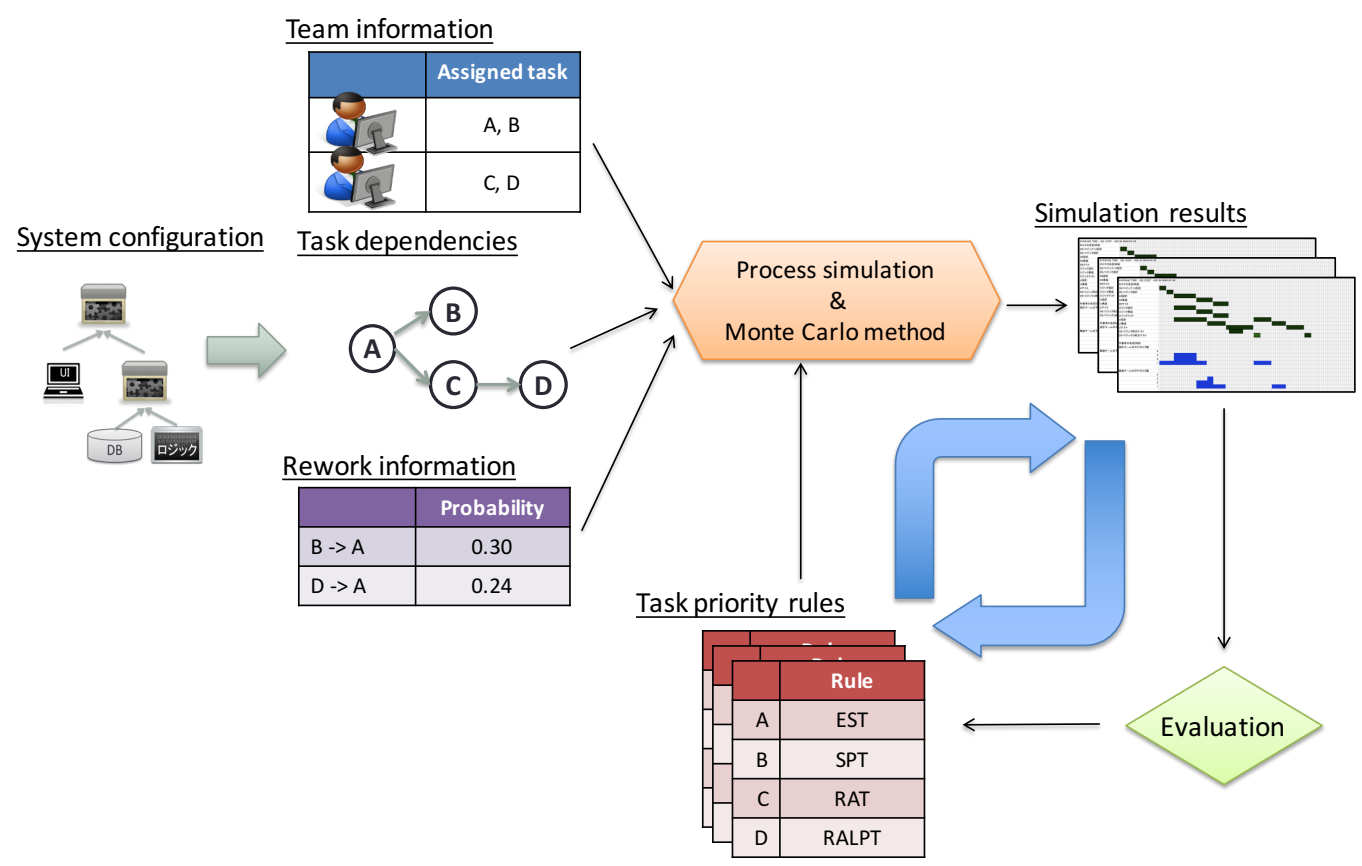

Fig. 1 Overview of proposed methodology.

\section{$2 \cdot 1$ システム構成からタスクの依存関係の導出}

システム開発プロジェクトで対象となるシステムは，それぞれ機能を持つ各モジュールによって構成される. また，モジュール間でも親子関係を持ち，どのモジュールもこれ以上分解出来ない最下位のモジュールにまで分 解することが可能である．例えば，Web で情報を入力しデータベースに保存するという簡単なシステムを考えた 場合, 入力画面としての Webインターフェイスと, データベース, データベースに保存するためのロジックが開 発に必要な部品として必要になる．開発するシステムの構成を考えた場合，データベースとデータベースに保存 するためのロジックを結合させたものをモジュールとし, 入力画面としての Webインターフェイスとこのモジュ 一ルを結合させることで開発目的とするシステムが完成する．提案手法では，システム構成情報を入力としてタ スクの依存関係を機械的に記述する，その具体例を図 2 に示す。まず，最上位のモジュールの「Design」タスク を設定し，それに依存して構成されるモジュールの「Design」タスクを設定する．さらに，そのモジュールに依 存して構成されるモジュールの「Design」タスクを設定するというように, 再帰的に全モジュールについて「Design」 タスクを設定する. 次に, 各最下位のモジュールについて,「Implement」タスクと「Test」タスクを連続して設定 する．その後，その上位のモジュールの「Integrate」タスクを，結合元となるモジュールの「Test」タスクに依存 
する形で設定する. 同様に, 上位モジュールの「Integrate」タスクを再帰的に設定し, 最上位モジュールの「Integrate」 タスクが設定された時点でタスクの依存関係全体が導出される.

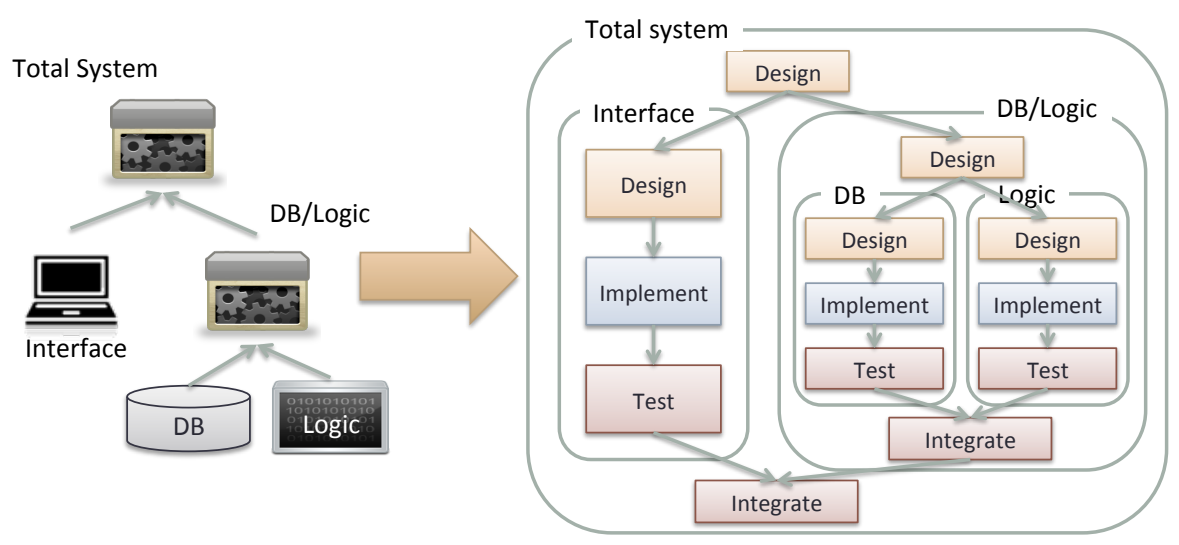

Fig. 2 Creating task dependencies from the information of system configuration

\section{$2 \cdot 2$ 手戻り確率を含めたワークフロ一情報の作成}

タスクの依存関係を導出した後に, 各タスクに求められる必要作業量を入力することでワークフロー情報 $\mathbf{W}$ を作成する. さらに, 後述するプロセスシミュレーションで手戻りを考慮するために, 入力データとして手戻り 確率を設定する．具体的には，ワークフロー情報の中で，どのタスクからどのタスクへの手戻りがどの程度の確 率で発生するのかを定義する。これによって, 手戻り確率の情報が含まれたワークフロー情報が生成される.

\section{$2 \cdot 3$ 人員の担当タスク情報}

$2 \cdot 2$ で作成したワークフロー情報を元にして，各タスクを担当する人員の情報である $\mathbf{S}$ を定義する. 具体的に は，人員 $m$ に関して，タスク $a$ に対するスキル值 $S_{m, a}$ を定義することによって人員の担当タスク情報とスキルセ ットからなる $\mathbf{S}$ を定義する. スキル值 $S_{m, a}$ は, 人員 $m$ がタスク $a$ の作業のみを行う場合の作業の進捗量を表す. ここで, $S_{m, a}=0$ の時には，人員 $\mathrm{m}$ はタスク $a$ の担当でない時を表し, $S_{m, a}>0$ の時には人員 $m$ はタスク $a$ の担当 であり, 単位時間のうちタスク $a$ を達成するために必要な作業量のうち $S_{m, a}$ だけ消費することが可能であること を示している.

\section{$2 \cdot 4$ タスク優先ルール}

RCPSP を含むスケジューリング問題では, 単一のディスパッチングルールを用いてどのタスクを優先して行う べきかを決める手法が数多く提案されているが，本研究では複数のディスパッチングルールによって構成される タスク優先ルールを用いる手法を提案する. タスク優先ルール $\mathbf{R}$ の定義を式(1)と式(2)に示す. タスク優先ルール は，ワークフロー情報 $\mathbf{W}$ に登録されている $N_{A}$ 個の各タスクに対して，予め用意したディスパッチングルール群 の中から 1 選択して登録したディスパッチングルールの集合によって構成される．２.5 で説明する手戻りを考 慮したプロセスシミュレーションにおいて，あるタスク $a$ が新たに作業人員を割当可能になった場合に，他の割 当可能なタスク群を含めてどのタスクを優先して行うかを決定する指標としてタスク $a$ に登録されているディス パッチングルール $r_{a}$ を用いる.

$$
\begin{aligned}
& \mathbf{R}=\left[r_{1}, r_{2}, \ldots, r_{N_{A}}\right] \\
& r_{i} \in\{T S L A C K, E S T, S P T, R A T, R A L P T\}
\end{aligned}
$$

なお，ディスパッチングルールに関しては様々なルールが既に提案されているが，後のケーススタディで取り 扱う問題で各タスクの納期を考えていないため, 納期に関するルール以外のものから代表的なものとして 
TSLACK と EST, SPTの 3つを採用し，手戻りを考慮したルールとして，本研究のケーススタディで取り扱う問 題に適用可能なルールとして新たに作成したルールである RAT とRALPT の 2 つを採用した.

- TSLACK (Total SLACK time)

- $\quad$ EST (Earliest Start Time)

- $\quad$ SPT (Shortest Processing Time)

- RAT (Rework Affecting Time)

- RALPT (Rework-Adjusted Long Processing Time)

TSLACK の定義を式(3)に示す. TSLACK はクリティカルパスに近いタスクを優先して行うというルールであ る. 具体的には，ある時刻 $t$ において，実行可能なタスク群 $\mathbf{A}(t)$ の中からどのタスクを優先して実行するべきか を決定する際に, PERT によって算出された最遅終了時刻 $L F T_{a}$ と最遅開始時刻 $L S T_{a}$ の差が小さいタスク $a$ を選 択するというルールである。

$$
a=\underset{a \in \mathbf{A}(t)}{\operatorname{argmin}}\left(L F T_{a}-L S T_{a}\right)
$$

EST の定義を式(4)に示す. EST はある時刻 $t$ において, 実行可能なタスク群 $\mathbf{A}(t)$ の中からどのタスクを優先し て実行するべきかを決定する際に，PERTによって算出された最早開始時刻 $E S T_{a}$ が最も小さいタスク $a$ を選択す るというルールである。

$$
a=\underset{a \in \mathbf{A}(t)}{\operatorname{argmin}}\left(E S T_{a}\right)
$$

SPT の定義を式(5)に示す. SPT はある時刻 $t$ において, 実行可能なタスク群 $\mathbf{A}(t)$ の中からどのタスクを優先し て実行するべきかを決定する際に，必要作業量 $d_{a}$ が最も小さいタスク $a$ を選択するというルールである.

$$
a=\underset{a \in \mathbf{A}(t)}{\operatorname{argmin}}\left(d_{a}\right)
$$

RAT の定義を式(6)に示す. RAT は Cooper らが提案している RPW（Rank Positional Weight）（Cooper, 1976）を 本研究で対象とする問題に適用可能なように拡張したものであり, ある時刻 $t$ において, 実行可能なタスク群 $\mathbf{A}(t)$ の中からどのタスクを優先して実行するべきかを決定する際に, 対象とするタスク $a$ の必要作業量 $d_{a}$ とタスク $a$ からの手戻りによって影響するタスク群 $\mathbf{A}_{a}$ における必要作業量の合計值を足しあわせた值に，手戻りが発生す る確率 $\mathrm{c}_{\mathrm{a}}$ を掛け合わせた值が最も大きいタスク $a$ を選択するというルールである. なお，ここで言う「タスク $a$ からの手戻りによって影響するタスク群 $\left.\mathbf{A}_{a}\right\rfloor$ とは, 次節のプロセスシミュレーションで使用するワークフロー情 報によって定義されるものであり，例えば一直線のワークフローにおいて，あるタスク $a$ から先頭のタスクへの 手戻りで影響されるタスク群 $A_{a}$ とは，そのワークフローに含まれる全てのタスクを指す. また，タスク $a$ から手 戻りが発生する先が複数登録されている場合, 手戻りが発生する確率 $\mathrm{c}_{\mathrm{a}}$ は複数の手戻り確率の合計值として算出 する.

$$
a=\underset{a \in \mathbf{A}(t)}{\operatorname{argmax}}\left(c_{a} \cdot\left(d_{a}+\sum_{a^{\prime} \in \mathbf{A}_{a}} d_{a^{\prime}}\right)\right)
$$

RALPT の定義を式(7)に示す. RALPTについてはCho らが提案している RARPW (Rework-Adjusted Rank Positional Weight）（Cho and Eppinger, 2005） を本研究で想定する問題に適用可能なように拡張したものであり，ある時刻 $t$ において，実行可能なタスク群 $\mathbf{A}(t)$ の中からどのタスクを優先して実行するべきかを決定する際に，タスク $a$ か らの手戻りによって影響するタスク群 $\mathbf{A}_{a}$ に登録されているタスクに関して，手戻りが発生する確率に 1 を加え たものと必要作業量を掛け合わせた值を, そのタスクの最遅終了時刻と現在の時刻との差で割った值を算出し, それらの值を合計した值が最も大きいタスク $a$ を選択するというルールである. RALPT についてはRAT と比べ 
Mitsuyuki, Yamato, Hiekata, Moser, Isonuma, Okada and Oida,

て対象とするタスクの工数情報を用いておらず，手戻りによって影響する各タスクの工数情報のみを用いて優先 度を算出しているのが特徴である.

$$
a=\underset{a \in \mathbf{A}(t)}{\operatorname{argmax}}\left(\sum_{a^{\prime} \in \mathbf{A}_{a}} \frac{\left(1+c_{a^{\prime}}\right) \cdot d_{a^{\prime}}}{L F T_{a^{\prime}}-t}\right)
$$

\section{$2 \cdot 5$ 手戻りを考慮したプロセスシミュレーション}

$2 \cdot 2$ と $2 \cdot 3$ で生成した情報を入力としてプロセスシミュレーションを行うことで, 対象とするシステム開発 プロジェクトがどのように行われるかを定量的に把握することができる．本研究では，満行らが実装した設計プ ロセスシミュレータ（満行他，2013）に，手戻りの概念とタスク優先ルールを加えたプロセスシミュレータを用 いる. ただし，本研究では「人員 1 人が同時に複数の作業を行わない」かつ「各タスクは 1 人の人員で行うもの とし，複数の人員で協力して行うことは考えない」という条件のもとにシミュレーションを行うものとする．開 発したプロセスシミュレータによる処理を以下に示す.

i. $\quad$ 時刻 $t=0$ とし，ワークフローにおける先頭のタスクの状態を「待機」とする

ii. 時刻 $t$ において状態が「待機」のタスク群を抽出する

iii. 時刻 $t$ において手の空いている人員群を抽出する

iv. 抽出したタスク群に対してタスク優先ルールを適用し，人員を割り当てる優先順位を決定する

v. 優先順位に従ってタスクを抽出し, 手の空いている人員のうち $S_{m, a}>0$ を満たす人員が存在する場合には, その人員に抽出したタスクを割り振る

vi. 割り振られたタスクの状態が「待機」の場合，タスクの状態を「作業中」に変更する

vii. スキル值に $S_{m, a}$ に従って, 各タスクの残り作業量を減らす

viii. 残り作業量が 0 以下のタスクが存在した場合, 手戻り確率の情報に従って手戻り判定を行う.

ix. 対象のタスク対する手戻り確率の情報が存在しない, または手戻りが発生しなかった場合, そのタスクの 状態を「終了」とし次のタスクを「待機」とする

x. 手戻りが発生した場合, 手戻り先のタスクとそのタスクに依存する全てのタスクの状態を「待機」, 必要 な作業量を初期值に変更する

xi. 』すべてのタスクの状態が「終了」でない場合， $t=t+1$ としてii.に戻る

なお，iv.における「抽出したタスク群に対してタスク優先ルールを適用」に関しては，ある時刻 $t$ において， 時刻 $t-1$ の時点で初めて状態が「待機」となったタスク $a$ に登録されているディスパッチングルール $r_{a}$ を採用し て時刻 $t$ における状態が「待機」のタスク群に対して優先付けを行い, その優先付けに従って人員を割り振るこ

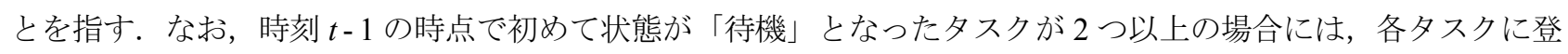
録されているディスパッチングルールから採用するディスパッチングルールをランダムで 1 つ選択する.

\section{$2 \cdot 6$ 遺伝的アルゴリズムによるタスク優先ルールの算出}

本研究では, $2 \cdot 5$ の手戻りを考慮したプロセスシミュレーションを用いて適切なタスク優先ルールを算出する 手法として, 遺伝的アルゴリズムによるタスク優先ルール探索手法を採用する. 具体的には, 遺伝的アルゴリズ ムにおける変数をタスク優先ルール $\mathbf{R} と し$, 遺伝子のコーティングについてはタスク優先ルール $\mathbf{R}$ における各 $r_{a}$ を遺伝子として, 各 $r_{a}$ において $2 \cdot 5$ で述べた 5 つのディスパッチングルールからどれを登録するべきかを探索 寸る. 探索における目的関数を式(8)に示す. $\operatorname{Sim}\left(\mathbf{W}, \mathbf{S}, \mathbf{R}, \varepsilon_{i}\right)$ は $2 \cdot 5$ の手戻りを考慮したプロセスシミュレーシ ヨンを表しており，プロセスシミュレーションの結果における所要時間が出力される．手戻りを考慮したプロセ スシミュレーションでは, 各タスクで手戻りが発生するかどうかと, 同時に複数のタスクが開始可能なときにど のディスパッチングルールを採用するかの 2 箇所においてランダム性が存在するため, 結果が一定にはならない. 式(8)における $\varepsilon_{i}$ は $i$ 回目のプロセスシミュレーションにおけるランダム性を表現している. したがって, 目的関 
数はモンテカルロ法を用いて $2 \cdot 5$ の手戻りを考慮したプロセスシミュレーションを複数（式(8)における $N_{s} ）$ 回 行い，それぞれのプロセスシミュレーションの結果における所要時間の平均值として探索する。 また，遺伝的ア ルゴリズムの探索を行う際には, 遺伝子群の更新のたびに交叉と突然変異を一定の割合で発生させて探索を行う.

$$
\text { Minimize } \frac{1}{N_{s}} \sum_{i=1}^{N_{s}} \operatorname{Sim}\left(\mathbf{W}, \mathbf{S}, \mathbf{R}, \varepsilon_{i}\right)
$$

\section{3. ケーススタディ}

\section{$3 \cdot 1$ 問題設定}

本章では，システム開発プロジェクトを対象に手戻りを考慮したプロセスシミュレーションを実施する際に， 単一のディスパッチングルールを用いた場合と，提案手法によって探索したタスク優先ルールを用いた場合でプ ロセスシミュレーションの結果にどのような差が出るかについて分析することで, 提案手法の有用性を検証する. 今回のケーススタディで開発対象としたシステムの構成と，システムの構成から算出されるタスクの依存関係情 報に各タスクの必要作業量と手戻り確率を付与して作成したワークフロー情報を図 3 に示寸．対象とするシステ ムは「Interface」と「Logic」と「DB」から構成されるシステムであり，ワークフロー情報を作成する際に，「DB」 に関連するタスクに関しては必要作業量が大きいかつ手戻り確率が小さく，「Interface」に関するタスクに関して は手戻り確率が他のタスクに比べて大きくなるように問題を設定した．また，今回のケーススタディでは，タス ク優先ルールの違いが結果に与える影響の最も大きいケースとして，対象とするシステム開発プロジェクトを行 う人員は 1 人のみとし，その人員のスキル情報は全てのタスクに関するスキル值を 1 として設定する．また，タ スク優先ルールを探索する際の遺伝的アルゴリズムの設定として個体数 100 , 世代数 5000 , 交叉率 0.75 , 突然変 異率 0.05 を採用し，モンテカルロ法における手戻りを考慮した繰り返し回数は 1000 回とした.

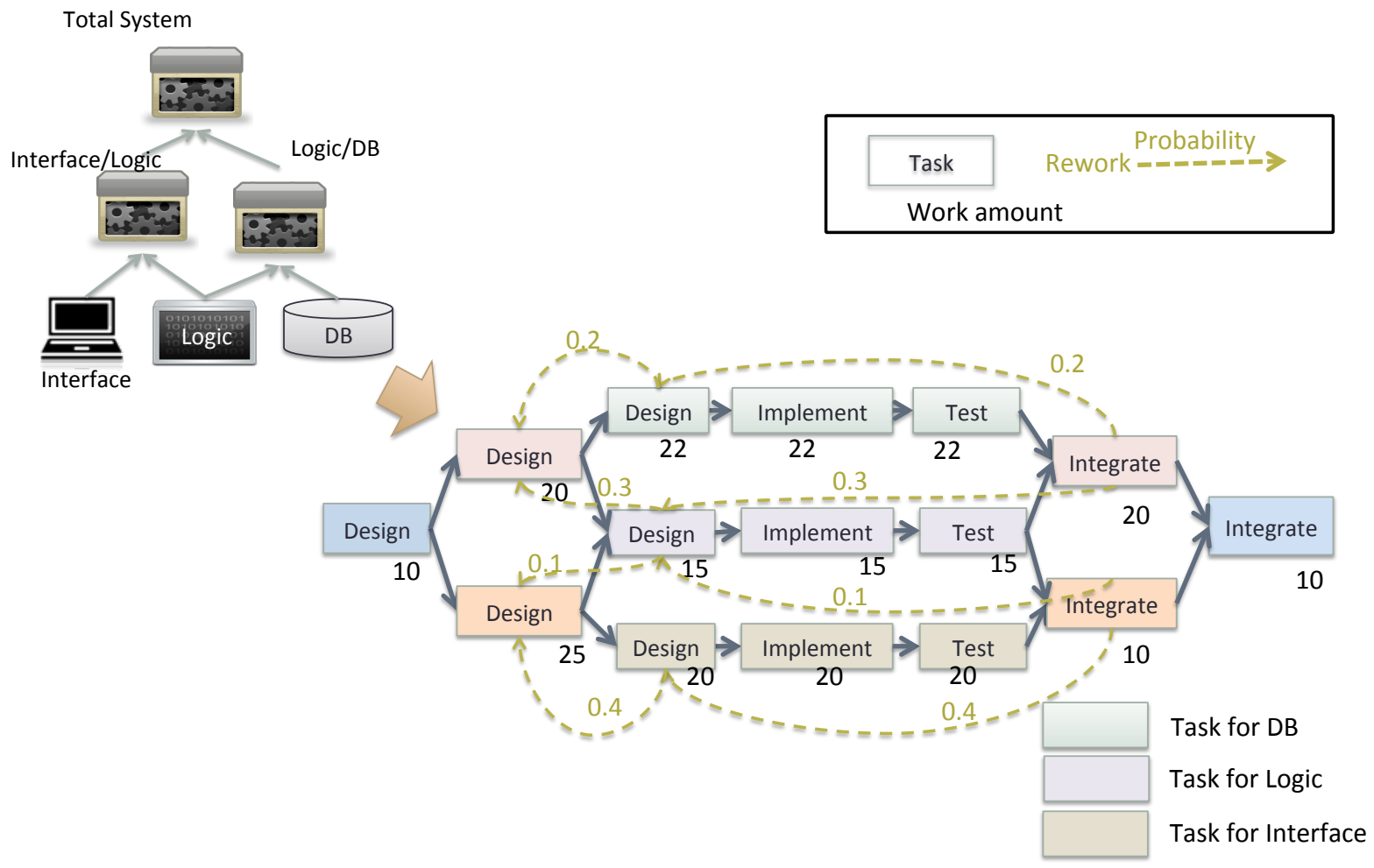

Fig. 3 Configuration of target system and workflow including the information of rework probabilities

\section{$3 \cdot 2$ 結果}


Mitsuyuki, Yamato, Hiekata, Moser, Isonuma, Okada and Oida,

提案手法によって算出されたタスク優先ルールを図 4 に示寸. 図 4 ではタスク優先ルールにおけるワークフロ 一内の各タスクに登録されたディスパッチングルールを図 3 のワークフロー図と対応させて記述している. 今回 のケーススタディでは 1 人の人員が並行作業をすることなく作業を行っていることを考えると, 手戻りが起こり や寸いタスクに紐付けられて登録されているディスパッチングルールがRAT またはRALPTになっており，これ らのタスクは実施可能な状態になった場合には早めに作業に取り掛かるべきであるというタスク優先ルールが算 出されていることが分かる.

提案手法によって探索した図 4 のタスク優先ルールを用いた場合と, タスク優先ルールに登録する候補となる 各ディスパッチングルールを単体で用いた場合を比較した結果を表 1 と図 5 に示す. 図 5 より, 各ディスパッチ ングルールを単体で使用した場合と図 4 のタスク優先ルールを用いた場合の結果の分布の形状は同じ形になって いることが分かる．また，表 1 より，RAT とRALPT は他の単一のディスパッチングルールと比較して平均所要 時間が大幅に減少していること，また提案手法によって探索されたタスク優先ルールは，それら 2 つディスパ ッチングルールと比較しても平均所要時間が減少していることが分かる．以上より，今回のケーススタディにお いて提案手法によって算出されたタスク優先ルールは，手戻りを考慮したプロセスシミュレーションの結果にお ける平均所要時間を減少させることに有用であると言える.

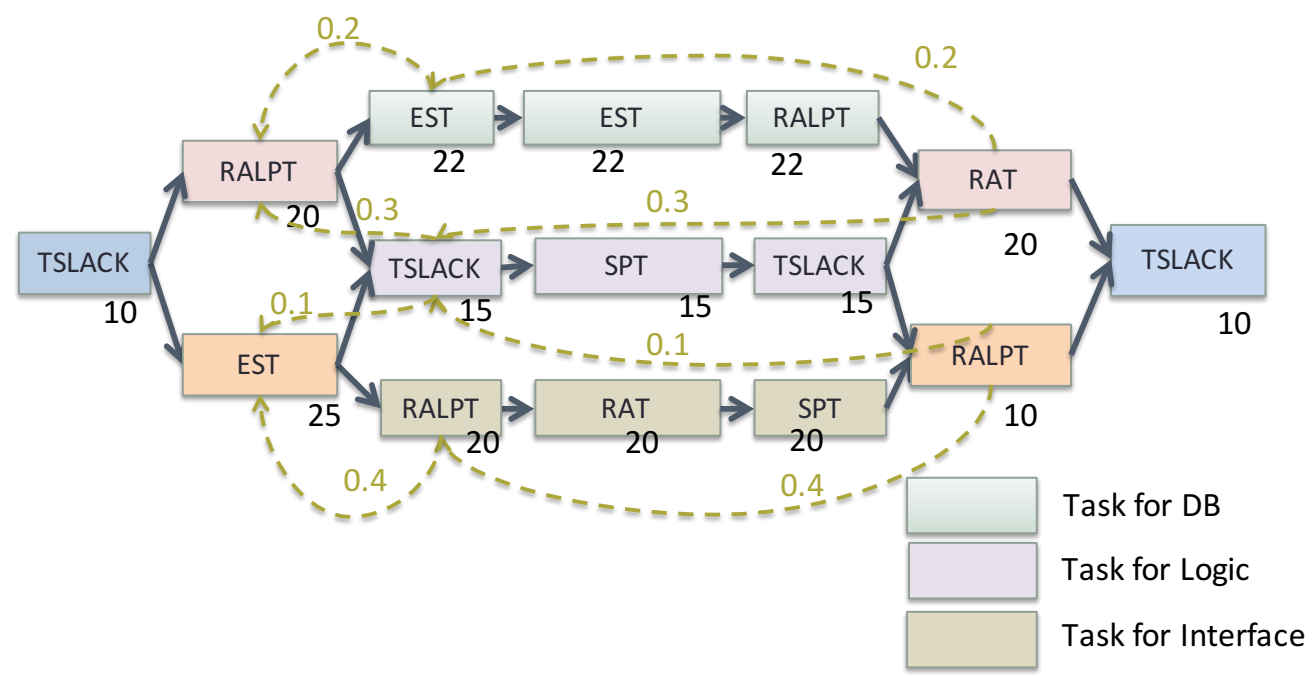

Fig. 4 Task priority rule calculated by proposed methodology. From the information of this task priority rule, high rework probability tasks and tasks which are deployed near high rework probability tasks will be done preferentially.

Table 1 Average time required of simulation results by each rule. From this table, task priority rule which is calculated by proposed methodology is the lowest average time required of simulation results. In addition, RAT and RALPT which are the dispatching rules considering rework have better average time required than other dispatching rules.

\begin{tabular}{c|c}
\hline \hline Rule & Average time required \\
\hline TSLACK & 664.3 \\
\hline SPT & 617.9 \\
\hline EST & 606.7 \\
\hline RAT & 590.7 \\
\hline RALPT & 590.6 \\
\hline Task priority rule & 571.7 \\
\hline (calculated by proposed methodology) & \\
\hline
\end{tabular}


Mitsuyuki, Yamato, Hiekata, Moser, Isonuma, Okada and Oida,

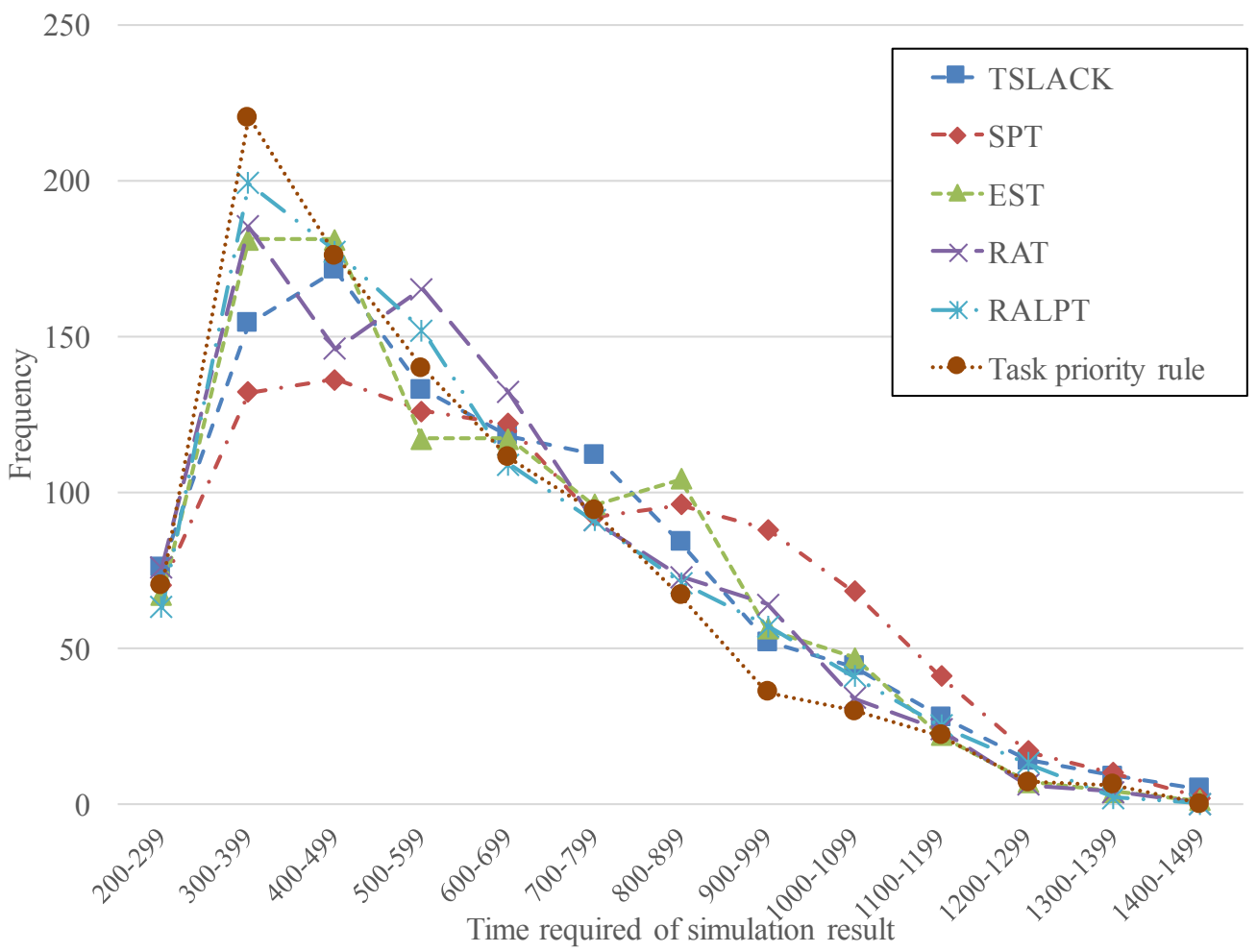

Fig. 5 Frequency of time required of simulation results by each rule. From this figure, distribution shape of frequency by each rule is similar to others. In addition, task priority rule has the lowest frequency of time required of simulation result.

\section{4. 考 察}

今回のケーススタディにおけるタスク優先ルールの探索範囲は, 用いたディスパッチングルールが 5 個であり, タスクの数が 15 個であるため, $5^{15}$ 通りのタスク優先ルール候補から探索している. 本研究では, 探索に遺伝的 アルゴリズムを用いている以上，算出されたタスク優先ルールの最適性は保証されない，一方で，今回のケース スタディにおけるタスク優先ルールの探索履歴を分析すると，評価結果の良いタスク優先ルールにおいて，手戻 りが発生するタスクには RAT または RALPT という手戻りを考慮したディスパッチングルールが登録されてお り, 手戻りが発生しない部分に属するタスクに関してはTSLACK やEST, SPT という手戻りを考慮しないディス パッチングルールが登録されているという傾向が見られた. 図 4 のタスク優先ルールを用いた場合と RAT のみ を用いた場合で，「Integrate (DB,Logic)」タスクから「Design (Logic)」タスクへの手戻りが 1 回発生した場合にお けるシミュレーション結果の違いを図 6 に示寸. 図 6 は各タスクがいつ実施されたかをガントチャート形式で可 視化しており，「Integrate (DB,Logic)」タスクから「Design (Logic)」タスクへの手戻りを矢印で表示している. 図 6 の上部は図 4 のタスク優先ルールを用いた場合の結果を, 図 6 の下部はディスパッチングルール RAT を用いた 結果を示している. それぞれのシミュレーション結果における所要時間は 331 と 341 であった. 単に RAT のみの ディスパッチングルールのみを用いる場合ではこの手戻りの発生によって「Integrate(Logic, Interface)」タスクを 2 回実施することになるため, 結果として所要時間が 10 だけ減少していることが分かる. この手戻りが発生する手 戻り確率は 0.3 と他に比べて割と高い值が設定されており, 提案手法によって「Integrate(Logic, Interface)」タスク を複数回実施することを避けるようにタスク優先ルールが設計されていることが分かる. また, 「Integrate (DB,Logic)」タスクから「Design (Logic)」タスクへの手戻りが複数回発生した場合は, この影響は更に大きくな る. よって, 提案手法は単一のディスパッチングルールを用いるよりも, 所要時間短縮の観点からより良いタス ク優先ルールを得られることが期待でき，手戻りを考慮したスケジュール設計に有効であると考える. 
Mitsuyuki, Yamato, Hiekata, Moser, Isonuma, Okada and Oida,
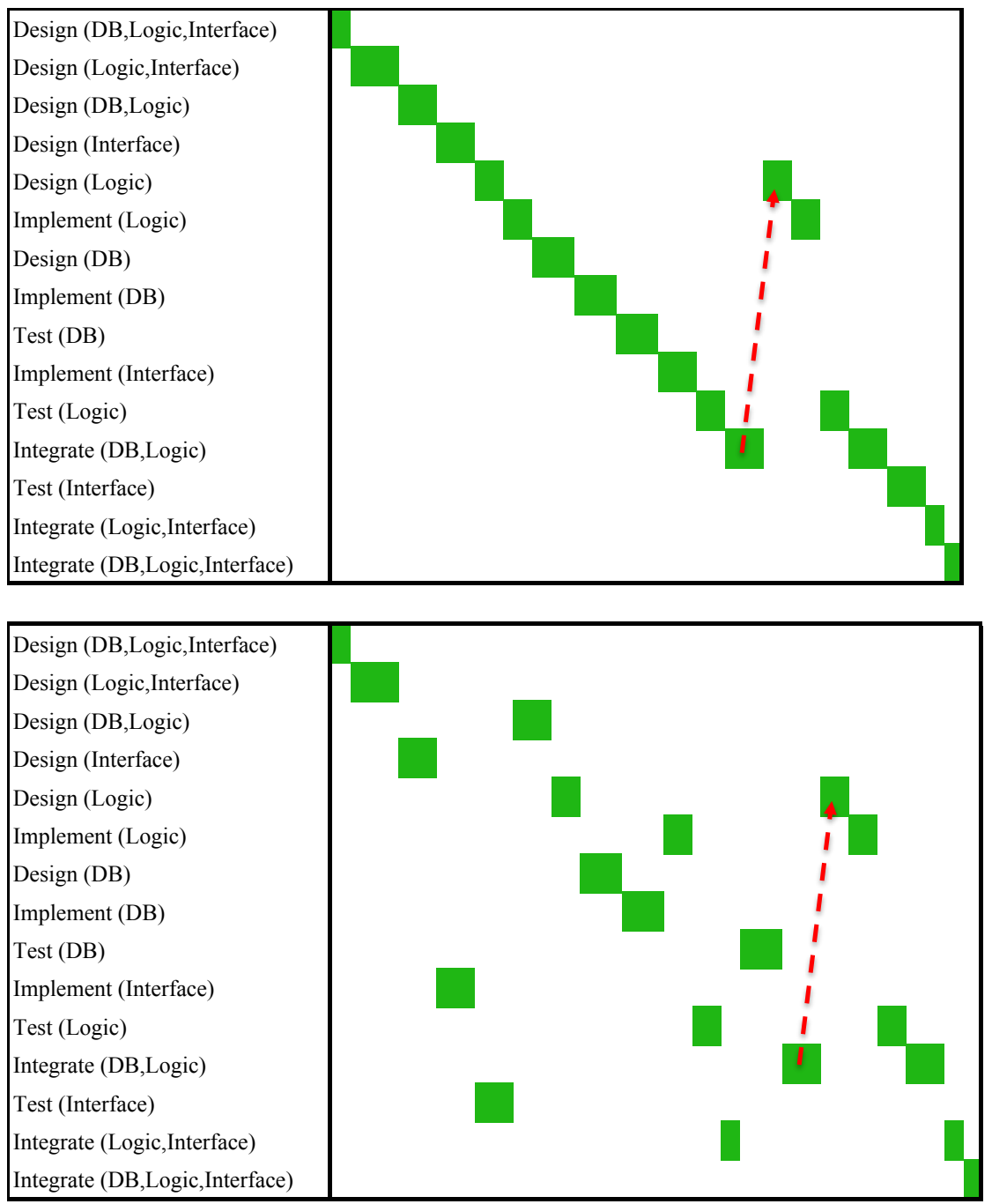

Fig. 6 Gantt charts of simulation results by using Fig.4 (upper chart) and RAT rule (lower chart). Horizontal axis shows time. Color boxes express the active time of each task. Dotted arrows express rework information from "Integrate (DB,Logic)" task to "Design (Logic)" task. From this figure, task priority rule can decrease the time required better than RAT in the case of this pattern.

一方で，後工程のタスク数が多いタスクに関しては，そのタスクの終了後には状態が「待機」に変更されたタ スクが同時に複数発生することになる，そのため，タスク優先ルールを適用する際には，後工程のタスク数が多 いタスクが終了後に状態が「待機」に変更された複数のタスクに登録されているディスパッチングルール群から 1つをランダムに選択することになり, 提案手法の結果はランダム性の影響を受けることになる.しかしながら， 提案手法によって適切なタスクから実行するように各タスクに適切なディスパッチングルールを登録しタスク優 先ルールを設計することで，上記のランダム性をある程度吸収できると考える。

また，提案手法を実際の問題に適用する際に，手戻り確率をどのように設定するかが課題として挙げられる. 各タスクの難易度やどのタスクへ手戻りが発生する可能性があるかについては，対象のタスクで行う作業の詳細 な分析や開発する情報システムの構造からある程度の推定が可能であるが，手戻り確率の值については直接に推 定を行うのは難しい。 一方で, 情報システム開発を行う企業では, 企業が明示的に保持している標準プロセスに 沿ってプロジェクトを実施することが多く, 対象とする情報システム開発プロジェクトと類似する過去の情報シ ステム開発プロジェクトの実績から手戻り確率の值を推定することで対応可能であると考える.

なお，今回のケーススタディにおいて手戻りが全く発生しないとした場合，プロジェクトの各タスクを実施す る人員が合計で 1 人，かつ人員が同時に 2 つ上のタスクを実施することができないという設定のため，各ディ スパッチングルールを用いた場合とタスク優先ルールを用いた場合において, タスクの実行順番に違いはあるが, 
最終的な所要時間に差は存在しない，また，複数の人員で実施する，または人員が同時に 2 つ上のタスクを実 行可能な場合では, 各時間で複数のタスクが実行可能になり, 結果としてタスク優先ルールが単位時間に実行す るタスクの決定に与える影響が弱くなる. 今回は, タスク優先ルールが与える影響の強いケース, すなわち各夕 スクを実施する人員が 1 人，かつ人員が同時に 2 つ上のタスクを実施することができないというケースを採用 してケーススタディを実施したが，複数の人員または同時に 2 つ上のタスクを実行可能な場合でも単一のディ スパッチングルールを用いるよりもより良いタスク優先ルールを得られることが期待できる.

\section{5. 結 言}

本研究では, システム開発プロジェクトにおける手戻りを含んだスケジュール設計のためのタスク優先ルール 設計手法を提案した。具体的には，各タスクの実施手順を決定する際に複数のディスパッチングルールの中から どれを選択するべきかを表すタスク優先ルールに対して, 遺伝的アルゴリズムを用いて決定する手法を提案した.

また，システム開発プロジェクトを対象に，提案手法の有用性を評価するケーススタディを行った．単一のデ イスパッチングルールを用いて手戻りを考慮したプロセスシミュレーションを行った結果に比べて, 提案手法に よって算出した複数のディスパッチングルールを含むタスク優先ルールを用いて手戻りを考慮したプロセスシミ ユレーションを行った結果では平均所要時間が短縮できることが確認でき, 提案した複数のディスパッチングル 一ルを含むタスク優先ルールが手戻りを考慮したスケジュール設計に有用であることが確認できた.

今後の展望として, ワークフローの構造に応じた最適なタスク優先ルールの分析と手戻り確率を決定する手法 の開発が考えられる．本研究では手戻り確率は設計者が与えるものとしているが，過去に行った情報システム開 発プロジェクトの情報から類似するプロジェクトのインシデントレポートなどの過去のトラブルや手戻りに関す る実績情報を抽出し利用することで, より現場に有用なタスク優先ルールとスケジュールの設計が可能になると 考えられる。

\section{文献}

Cho, S. H. and Eppinger, S. D., A simulation-based process model for managing complex design projects, Engineering Management, IEEE Transactions, Vol.52, No.3 (2005), pp.316-328.

Cooper, D., Heuristics for scheduling resource-constrained projects: an experimental investigation, Management Science, Vol.22, No.11 (1976), pp.1186-1194.

Hartmann, S., A competitive genetic algorithm for resource-constrained project scheduling, Naval Research Logistics, Vol.45, No.7 (1998), pp.733-750.

岩村幸治, 西濱大佑, 田中健太郎, 谷水義隆, 杉村延広, 生産計画を考慮した作業者の教育計画の作成手法に関す る研究，日本機械学会論文集, Vol.80, No.814 (2014), DOI: 10.1299/transjsme.2014trans0144.

Kolisch, R., Serial and parallel resource-constrained project scheduling methods revisited: theory and computation, European Journal of Operational Research, Vol.90, No.2 (1996), pp.320-333.

$\mathrm{Lu}, \mathrm{R}$. and Li, L., A heuristic approach for rework based product design project scheduling problem, Control and Decision Conference (2008), pp.1486-1491.

Merkle, D., Middendorf, M. and Schmecket, H., Ant colony optimization for resource-constrained project scheduling, evolutionary computation, IEEE Transactions, Vol.6, No.4 (2002), pp.333-346.

Mitsuyuki, T., Hiekata, K. and Yamato, H., Design of production strategy considering the cutting peak demand of electricity in the shipbuilding industry, Journal of Marine Science and Technology, Vol.19, No. 4 (2014), pp.425-437.

満行泰河, 大和裕幸, 稗方和夫, 複数設計業務のシミュレーションと組織内人員の最適配置, 日本機械学会論文集 C 編, Vol.89, No.806 (2013), pp.3930-3938.

Moser, B. R., Ralph, T. W. and Hiekata, K., Risk management in the design of engineering as sociotechnical systems, Proceedings of the 21st ISPE Inc international conference on concurrent engineering (2015), pp.635-646, DOI: 10.3233/978-1-61499-440-4-635.

阪口龍彦, 松本昂樹, 清水良明, 精密板金加工のためのネスティング・スケジューリング統合化の研究（部品の再 
配置によるネスティングの改良)，日本機械学会論文集, Vol.81, No.825 (2015), DOI: 10.1299/transjsme.14-00640.

Suzuki, Y., Yahyaei, M., Jin, Y., Koyama, H. and Kanga, G., Simulation based process design: modeling and applications, Advanced Engineering Informatics, Vol.26, Issue.4 (2012), pp.763-781.

鈴木陽一郎，小山秀夫，金雁，適切な技能伝承の進め方を定量的に選択する手法に関する研究（技能伝承過程にお ける生産プロセスのシミュレーションによる再設計），日本機械学会論文集, Vol.80, No.812 (2014), DOI: 10.1299/transjsme.2014dsm0107.

Valls, V., Ballestín, F. and Quintanilla, S., A hybrid genetic algorithm for the resource-constrained project scheduling problem, European Journal of Operational Research, Vol.185, No.2 (2008), pp.495-508.

\section{References}

Cho, S. H. and Eppinger, S. D., A simulation-based process model for managing complex design projects, Engineering Management, IEEE Transactions, Vol.52, No.3 (2005), pp.316-328.

Cooper, D., Heuristics for scheduling resource-constrained projects: an experimental investigation, Management Science, Vol.22, No.11 (1976), pp.1186-1194.

Hartmann, S., A competitive genetic algorithm for resource-constrained project scheduling, Naval Research Logistics, Vol.45, No.7 (1998), pp.733-750.

Iwamura, K., Nishihara, D., Tanaka, K., Tanimuzu, Y. and Sugimura, N., A study on education planning method for human operators considering production plans, Transactions of the JMSE (in Japanese), Vol.80, No.814 (2014), DOI: 10.1299/transjsme.2014trans0144.

Kolisch, R., Serial and parallel resource-constrained project scheduling methods revisited: theory and computation, European Journal of Operational Research, Vol.90, No.2 (1996), pp.320-333.

Lu, R. and Li, L., A heuristic approach for rework based product design project scheduling problem, Control and Decision Conference (2008), pp.1486-1491.

Merkle, D., Middendorf, M. and Schmecket, H., Ant colony optimization for resource-constrained project scheduling, evolutionary computation, IEEE Transactions, Vol.6, No.4 (2002), pp.333-346.

Mitsuyuki, T., Hiekata, K. and Yamato, H., Design of production strategy considering the cutting peak demand of electricity in the shipbuilding industry, Journal of Marine Science and Technology, Vol.19, No. 4 (2014), pp.425-437.

Mitsuyuki, T., Yamato, H. and Hiekata, K., Human resource allocation optimization for multiple design project using simulation, Transactions of the Japan Society of Mechanical Engineers, Series C, Vol.89, No.806 (2013), pp.3930-3938 (in Japanese).

Moser, B. R., Ralph, T. W. and Hiekata, K., Risk management in the design of engineering as sociotechnical systems, Proceedings of the 21st ISPE Inc international conference on concurrent engineering (2015), pp.635-646, DOI: 10.3233/978-1-61499-440-4-635.

Sakaguchi, T., Matsumoto, K. and Shimizu, Y., Study on nesting scheduling for sheet metal processing (improvement of nesting method by parts reallocation), Transactions of the JMSE (in Japanese), Vol.81, No.825 (2015), DOI: 10.1299/transjsme.14-00640.

Suzuki, Y., Yahyaei, M., Jin, Y., Koyama, H. and Kanga, G., Simulation based process design: modeling and applications, Advanced Engineering Informatics, Vol.26, Issue.4 (2012), pp.763-781.

Suzuki, Y., Koyama, H. and Jin, Y., A study on the quantitative method for choosing an appropriate skill developing strategy (a simulation based manufacturing process redesign for skill developing), Transactions of the JMSE (in Japanese), Vol.80, No.812 (2014), DOI: 10.1299/transjsme.2014dsm0107.

Valls, V., Ballestín, F. and Quintanilla, S., A hybrid genetic algorithm for the resource-constrained project scheduling problem, European Journal of Operational Research, Vol.185, No.2 (2008), pp.495-508. 